\title{
Microstructural formations during the production of Early Byzantine iron nails from Hadrianoupolis in Paphlagonia (north-central Turkey)
}

\author{
İ. M. Kuşoğlu \\ Dokuz Eylül University, Archaeometry Application and Research Center (DË̈ ARKEM), Torbalı Vocational School, \\ 7 Eylül Mah. 5562 Sokak No:9, TR-35860, Torbali, Izmir, Turkey
}

Received 30 September 2014, received in revised form 12 December 2014, accepted 27 January 2015

\begin{abstract}
Iron nails with different shapes and sizes were excavated from Hadrianoupolis in southwestern Paphlagonia located $3 \mathrm{~km}$ west of Eskipazar, the modern town near Karabük. Possible microstructural formations of iron based nails produced in Roman and Early Byzantine Period were examined in this study. Throughout the study chemical compositions of these iron based nails reflecting different microstructures were measured. According to our experimental results, we concluded that they were made of low carbon iron generally containing a number of non-metallic features indicating surface carburization and widmanstaetten formations. The effect of $\mathrm{P}$, As and $\mathrm{Ni}$ amounts in iron alloy was observed from chosen nails. These results revealed that the nails were produced by an iron technology based primarily on the bloomery technique completed by smith process based on hammering. Various microstructures were observed according to the production processes of the nail.
\end{abstract}

K e y w or d s: bloomery, smithing, iron nail, Early Byzantium, archaeometallurgy

\section{Introduction}

Hadrianoupolis is situated on the principal western route from the Central Anatolian Plain through the mountains into Bartm and the Black Sea. In Roman and Early Byzantine Paphlagonia, this site was located $3 \mathrm{~km}$ west of the modern town of Eskipazar, near Karabük. Hadrianoupolis and its extensive chores are situated between the mountainous areas of the western coastal Black Sea region and fertile Central Anatolian plateau. During and after the Roman and Early Byzantine periods, the region was a major source of timber, which was transported across great distances over the sea [1]. It was the largest Roman and Early Byzantine site in the Turkish Province of Karabük. During the late 5 th and early 6 th centuries, there was an upturn in the overall level and spread of the settlement, the urban centre of the ancient city in the south-western Paphlagonia included. Beginning from the early 6th century AD, it became an "upper-level" polis with a fortification and a building "boom" lay- ing on important trade routes, and became a regional centre.

The aim of the study is to present the results of archaeometric analysis on the iron nails found in Bath A as well as the Early Byzantine domus, from a time period ranging between 6 th to mid 7 th century $\mathrm{AD}$, during the seasons 2006 and 2008. The archaeological and archeometrical characteristics of the nails including their use, typology, chemical composition, production techniques and possible distribution have not been studied by many researchers so far. The wooden architecture in Early Byzantine Hadrianoupolis had an important effect on the use and also the number of nails in the area.

Ancient metallurgists had developed the bloomery process to gain tiny particles of iron metal which was stuck together to form spongy iron. Also, they employed the smithing process to produce iron objects to use in their civilizations.

In the bloomery process, iron ores are reacted with burning charcoal or woods for the reduction of non-

*Corresponding author: e-mail : $\underline{\text { murat.kusoglu@deu.edu.tr }}$ 
metallic iron compounds below the melting temperature of iron. This spongy iron is known as bloom. 'Tapping' furnaces used in the bloomery process, best known from the late Iron Age, Roman and medieval periods, have a hole at ground level in the furnace wall that could be opened during the smelt so that the slag could run out where the resulting tap slag has a capability of flowing [2]. Repeated reheating and hot hammering can eliminate much of the slag, creating wrought iron which is comparably a better product than bloom. Once wrought iron is gained, the next stage of iron working was to shape iron by smithing. In this process, the iron is heated in a hearth until it becomes red hot and malleable, and it is then hammered into shape on an anvil. Smithies do not have to be located near a smelting site; the smith could obtain a stock of iron through trade links. The smith heats the metal in a hearth that is often fuelled by charcoal, although coal was also used where available as long ago as the Roman period [2].

The physical and chemical properties of iron nails depend on the composition of iron ores, reaction temperature, and reduction efficiency by burning carbon during bloomery process, heating temperature, forging pressure and cycle, surface treatment, annealing duration and also quenching during smithing process [3-13]. All these parameters affect the metal structure which can be observed from the microstructure of the iron objects. Alloying iron with other elements can change the properties of the iron. One of the main alloying elements in iron matrix is carbon. The strength and hardness of the iron can be increased by addition of carbon which forms $\mathrm{Fe}_{3} \mathrm{C}$ named as cementite in iron structure. Critical ratio of $\mathrm{C}$ forms pearlite structure composed of cementite and ferrite. According to surface carburization rate and differences in cooling rate, widmanstaetten structure is formed in the transition of high to low carbon regions [14].

Other elements such as $\mathrm{P}, \mathrm{S}, \mathrm{Cu}, \mathrm{As}, \mathrm{Ni}, \mathrm{Mn}$, $\mathrm{Si}$ that are dissolved in spongy iron come from iron ores. The amounts of these alloying elements affect the formation of microstructures. $\mathrm{Cu}, \mathrm{Ni}, \mathrm{Co}$ and $\mathrm{As}$ can be reduced by carbon more easily than iron. The reduced element goes into solution in the extracted iron [15]. So these elements reflect more than the half of total amounts in the iron ore. These trace elements are adequate clues to define iron ores used as a raw material during bloomery iron production. It should be noted that chemical compositional differences can be found in nails because of their small size. The homogenization of trace elements that is distributed in the iron matrix may be difficult since the iron is not melted and mixed completely. Hammering (forging) deforms the microstructure where these composition changes can be observed easily by optical microscope [16]. Non-metallic inclusions distributed in the iron nails can be used to determine the level of reduc-

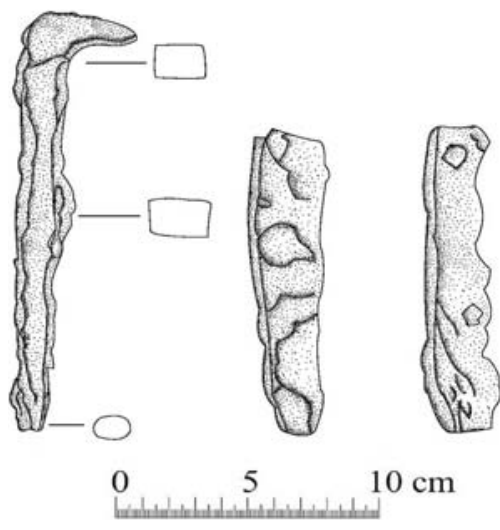

Fig 1. Types and shapes of the excavated iron nails.

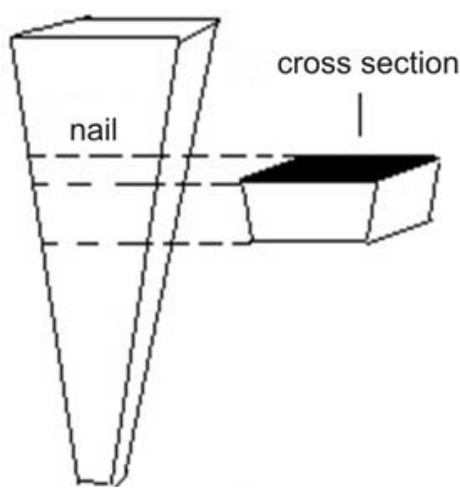

Fig. 2. Representation of investigated cross-section of nail.

tion and iron ore compositions by microstructural and chemical analysis [17].

\section{Experimental procedures}

In this article 32 pieces of ancient iron based nails from Hadrianoupolis used in constructions to join woods are investigated. The types and shapes of the nails can be seen in Fig. 1. For the observation of microstructures, the cross-sections of nails are cut as shown in Fig. 2, prepared in a metallographic way, and observed by inverted type optical microscopy (OM). Polished samples are observed to determine the distribution of inclusions in the microstructures before etching process. Then samples are etched by Nital $(2-$ 5 vol.\%) to observe the microstructures. Such eight samples are chosen to measure elemental compositions of nails by using Optical Emission Spectrometer (Thermo scientific ARL 4460) which is configured for low alloy steels. Scanning Electron Microscope (SEM) and Energy Dispersive Spectrometer (EDS) analysis are employed for detail investigations. 
Table 1. Elemental composition of investigated iron nails

\begin{tabular}{|c|c|c|c|c|c|c|c|c|c|c|c|c|c|c|}
\hline \multirow{2}{*}{ Sample } & \multicolumn{14}{|c|}{ wt.\% } \\
\hline & $\mathrm{C}$ & $\mathrm{Si}$ & $\mathrm{Mn}$ & $\mathrm{P}$ & $\mathrm{S}$ & $\mathrm{Cu}$ & $\mathrm{Ni}$ & As & $\mathrm{Sn}$ & $\mathrm{Pb}$ & $\mathrm{Mg}$ & $\mathrm{Al}$ & $\mathrm{N}$ & $\mathrm{Fe}$ \\
\hline 2 & 0 & 0 & 0 & 0.063 & 0.005 & 0.004 & 0.035 & $>0.46$ & 0 & 0.001 & 0 & 0 & 0.0260 & 99.330 \\
\hline 3 & 0.620 & 0.007 & 0.045 & 0.120 & 0.003 & 0.026 & 0.065 & 0.041 & 0.001 & 0.003 & 0.003 & 0.004 & 0.0051 & 98.880 \\
\hline 4 & 0.030 & 0.080 & 0 & 0.076 & 0.046 & 0 & 0.230 & 0 & 0 & 0 & 0 & 0.010 & 0.0300 & 99.100 \\
\hline 5 & 0.13 & 0.133 & 0.0043 & 0.158 & 0.0055 & 0.0068 & 0.0331 & 0.154 & 0 & 0 & 0.011 & 0.0071 & 0.0037 & 99.300 \\
\hline 6 & 0.100 & 0.016 & 0 & 0.067 & 0.001 & 0.019 & 0.090 & 0.065 & 0 & 0.001 & 0.002 & 0.007 & 0.0255 & 99.410 \\
\hline 10 & 0.090 & 0.050 & 0 & 0.040 & 0.002 & 0.020 & 0.100 & 0.110 & 0 & 0.001 & 0.030 & 0.009 & 0.0252 & 99.100 \\
\hline 12 & 0.0527 & 0.0172 & 0 & 0.130 & 0.010 & 0.0214 & 0.038 & $>0.42$ & 0.0016 & 0.002 & 0 & 0.003 & 0.0250 & 99.300 \\
\hline 21 & 0.121 & 0.182 & 0.0282 & 0.620 & 0.0281 & 0.0193 & 0.0399 & 0.157 & 0.0019 & 0.0066 & 0.0047 & 0.0281 & 0.0438 & 98.4 \\
\hline
\end{tabular}
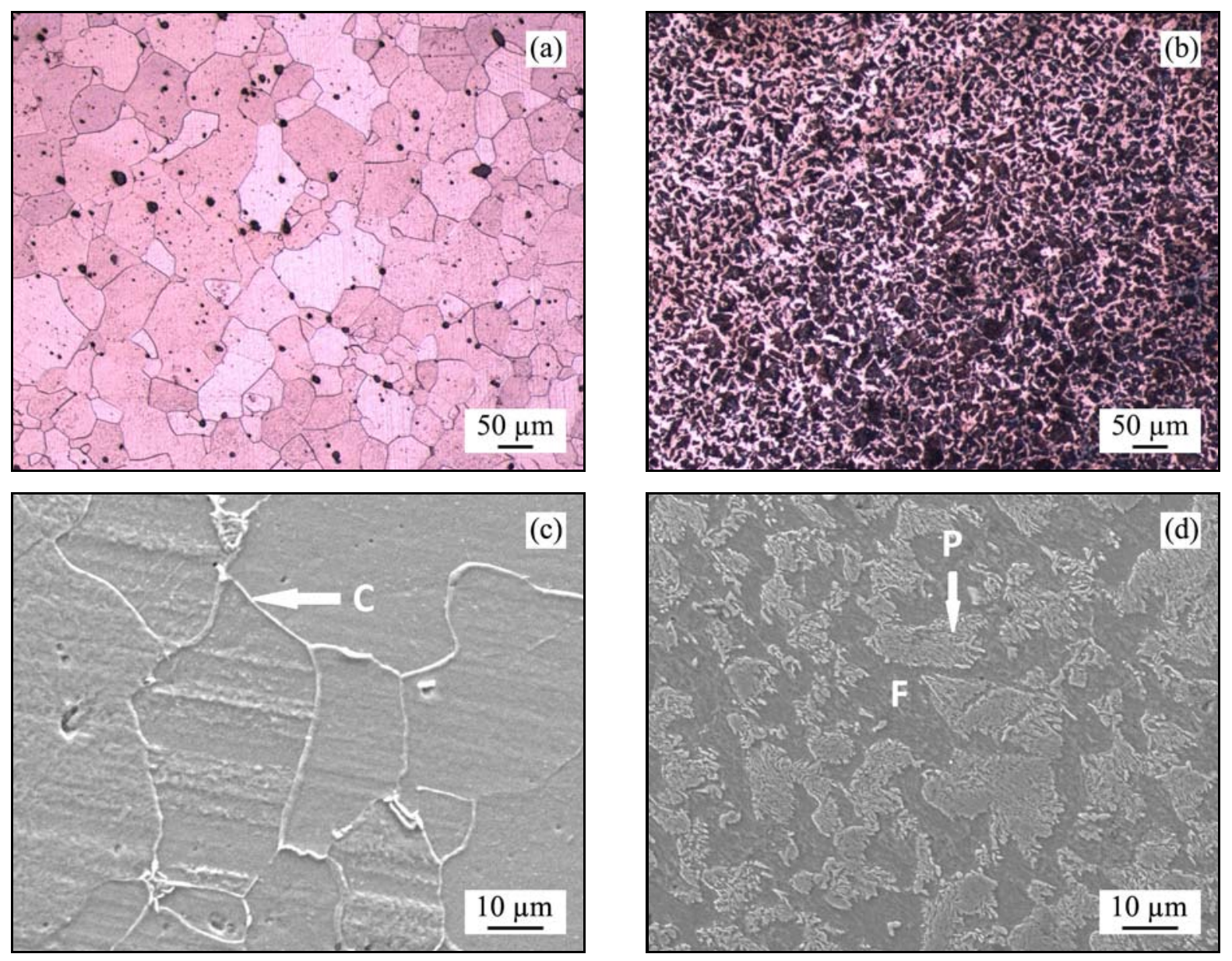

Fig. 3. Microstructures observed by OM for (a) sample 10 with 0.1 wt.\% C; (b) sample 3 with 0.62 wt.\% C; by SEM for (c) sample 10 with $0.1 \mathrm{wt} . \% \mathrm{C}$; (d) sample 3 with $0.62 \mathrm{wt} . \% \mathrm{C}$ (F: ferrite, C: cementite, P: pearlite).

\section{Results and discussion}

Eight nails are randomly chosen to determine their elemental compositions. The amounts of alloying elements determined by optical emission spectrometer are given in Table 1 . According to the results given in Table 1, alloying elements in the iron matrix are maximum 1.6 wt.\%. The amount of $\mathrm{C}, \mathrm{As}, \mathrm{P}, \mathrm{Ni}$ and $\mathrm{Si}$ is higher than the other alloying elements in the iron nails. The amount of alloying elements has a notable influence on the microstructural formations. On the other hand, hammering and annealing during smithing process have a significant effect for heterogeneous microstructural formations.

One of the main alloying elements found in iron is carbon due to the reaction between iron ore and carbon containing coal, charcoal or wood used in bloomery and smithing processes. The amount of carbon, 
atmosphere, heating temperature, annealing duration, cooling rate are the main factors affecting the microstructure of $\mathrm{Fe}-\mathrm{C}$ phases. In the hypo eutectoid zone during heating, ferrite, cementite $\left(\mathrm{Fe}_{3} \mathrm{C}\right)$ and austenite phases can be obtained. The carbon amount in the iron matrix is less than $0.13 \mathrm{wt} . \%$ except sample 3 which contains 0.62 wt.\% C. Carbon concentration ranges of the nails are in the hypo eutectoid zone in Fe-C phase diagram. Ferritic structure is dominant in this range. Homogeneously distributed equiaxed ferrite grains can be observed for sample 10 as in Fig. 3a,c. Also, microstructure composed of ferrite and pearlite grains can be observed for sample 3 as in Fig. 3b,d.

The effect of other alloying elements differs in the absence of $\mathrm{C}$ in the structure. In the bloomery process, the furnace temperature could be relatively low $\left(<1250^{\circ} \mathrm{C}\right)$, the reduction might be low, and virtually no manganese and silicon entered the metal phase. Chemical analyses usually disclose less than 0.02 $0.04 \mathrm{wt} . \%$ of each of these components in the metal phase [17]. The heat required to reduce $\mathrm{Si}$ and $\mathrm{Mn}$ oxides has to be over $1250^{\circ} \mathrm{C}$ whereas it is not possible to achieve this temperature in bloomery and smithing processes. If the amount of $\mathrm{Si}$ was higher, elimination of slags in the structure formed during bloomery process was not adequate. The amount of $\mathrm{Si}$ is higher than $0.04 \mathrm{wt} . \%$ in 3 samples and has a maximum value of 0.18 wt.\%. This is a sign of slag inclusions in the microstructure. The amount of $\mathrm{Mn}$ is below $0.03 \mathrm{wt} . \%$ and could not be detected in 5 samples. The similar bloomery heating technique is used for the samples investigated. The amount of detected $\mathrm{S}$ has no notable effect to the structure.

Many ancient iron objects contain zones with 0.2 $0.5 \mathrm{wt} . \% \mathrm{P}$, surrounded by $\mathrm{P}$-free iron or low carbon zones or both $[17,18]$. The amount of $\mathrm{P}$ is below $0.16 \mathrm{wt} . \%$ in 7 samples except sample 21 which is around 0.65 wt.\%. This amount has a significant effect on the microstructure as shown in Fig. 4. The segregation during smithing process forms rounded grains in the centre of sample 21 .

Table 1 is directing the importance of the amounts of $\mathrm{Ni}$ and $\mathrm{As}$ known as the trace elements. Low amounts of $\mathrm{Ni}$ also stabilize the austenite during heating and cooling. In Ni containing sample (sample 10) few twins were observed in recrystallized microstructure as shown by arrows in Fig. 5a. The maximum amount of Ni determined in sample 4 is $0.23 \mathrm{wt} . \%$. The microstructure of sample 4 is shown in Fig. 5b. On the other hand, As and P stabilize ferrite and decrease the high temperature rate of diffusion which also avoid or decrease the rate of carbon diffusion during smithing process.

The maximum amount of arsenic (As) in iron nails is found to be over $0.42 \mathrm{wt} . \%$ for sample 2 and 12 . The detection limit is $0.42 \mathrm{wt} . \%$ during measuring

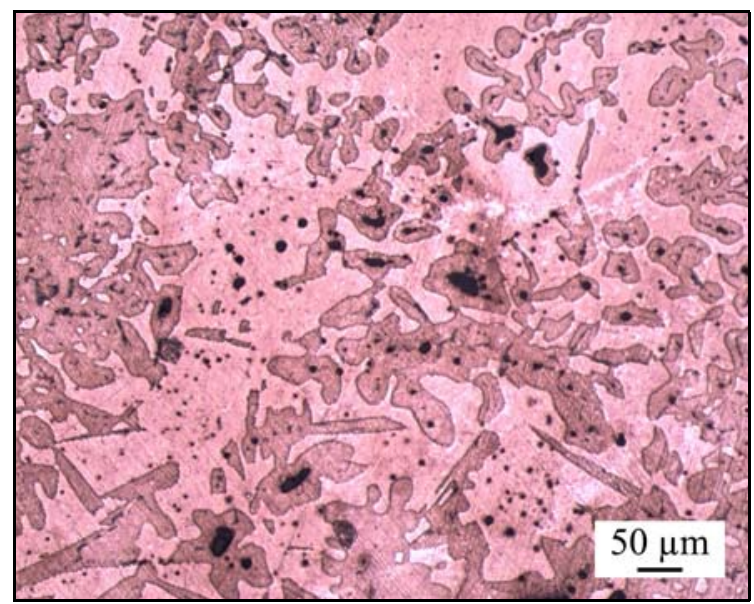

Fig. 4. The microstructure of 0.65 wt. $\% \mathrm{P}$ containing iron matrix at $100 \times$ magnification.
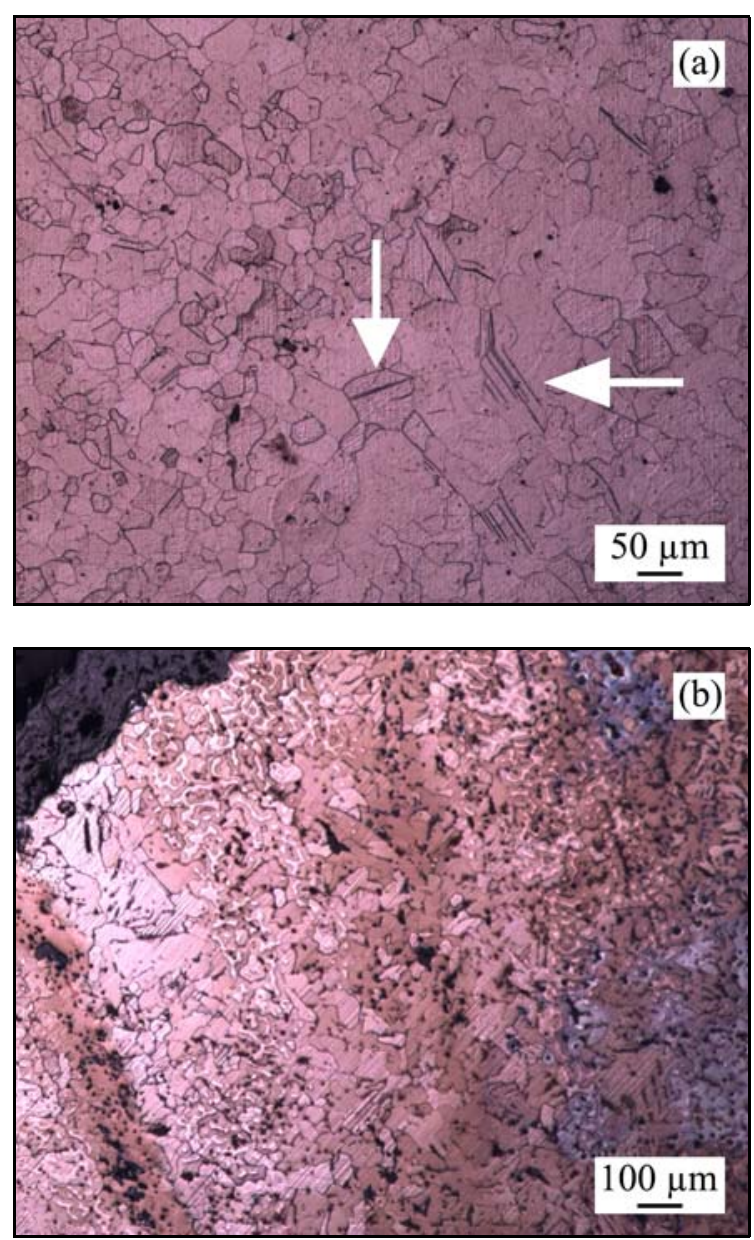

Fig. 5. Microstructural effect of (a) 0.1 wt.\% Ni and (b) 0.23 wt. $\% \mathrm{Ni}$ in iron matrix at (a) $100 \times$ and (b) $50 \times$ magnifications.

elemental compositions by optical emission spectrometer. The microstructures of sample 2 and 12 are given in Fig. 6. The heterogeneous distribution of As 

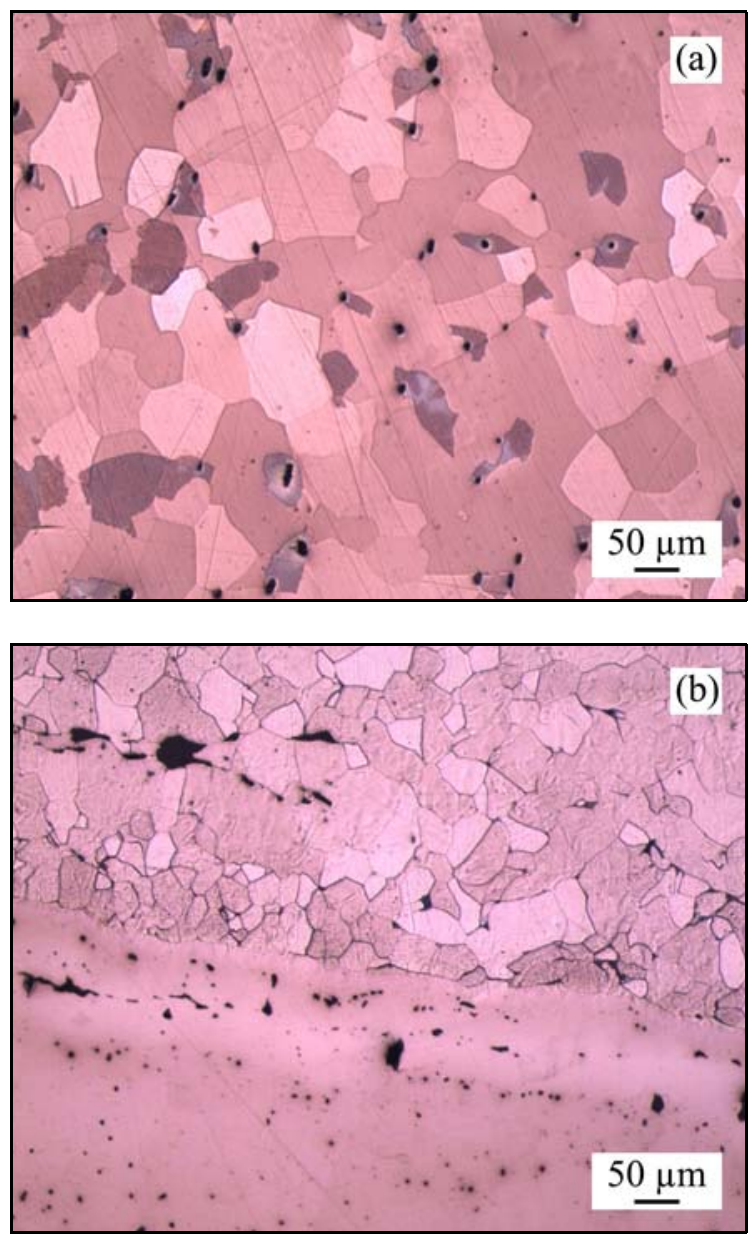

Fig. 6. Microstructures of over 0.42 wt.\% As containing iron matrix of sample (a) 2 and (b) 12 at $100 \times$ magnification.

in sample 12 is observed. There are notable transition grain boundaries between As rich and poor zones. Arsenic (As) rich zone is not affected by nital etchant for the observation of grain boundaries. As a common result of the observations, it is found that carbon (C) diffusion is not notable in $\mathrm{Ni}$, As or $\mathrm{P}$ containing iron zones. Surface carburization is only observed in the regions of samples where the amount of $\mathrm{Ni}$ and $\mathrm{As}$ is thought to be in less amount.

$\mathrm{Cu}$ is another trace element in the structure. The amount of $\mathrm{Cu}$ is around $0.02 \mathrm{wt} . \%$ for 5 samples. Similar iron ores might be used during the production of nails. The amounts of $\mathrm{Sn}, \mathrm{Pb}, \mathrm{Mg}, \mathrm{Al}$ are not high enough to observe their effects on the microstructure.

During the smithing process carbon $(\mathrm{C})$ diffusion can be higher on the surface. Carburization layers are also obtained on the surface of the microstructures as seen in Fig. 7 for samples 12 and 21. Carbon (C) diffusion through the surface strengthens the nail. The formation of pearlite rich zone grains surrounded by cementite transforms to widmanstaetten structure in
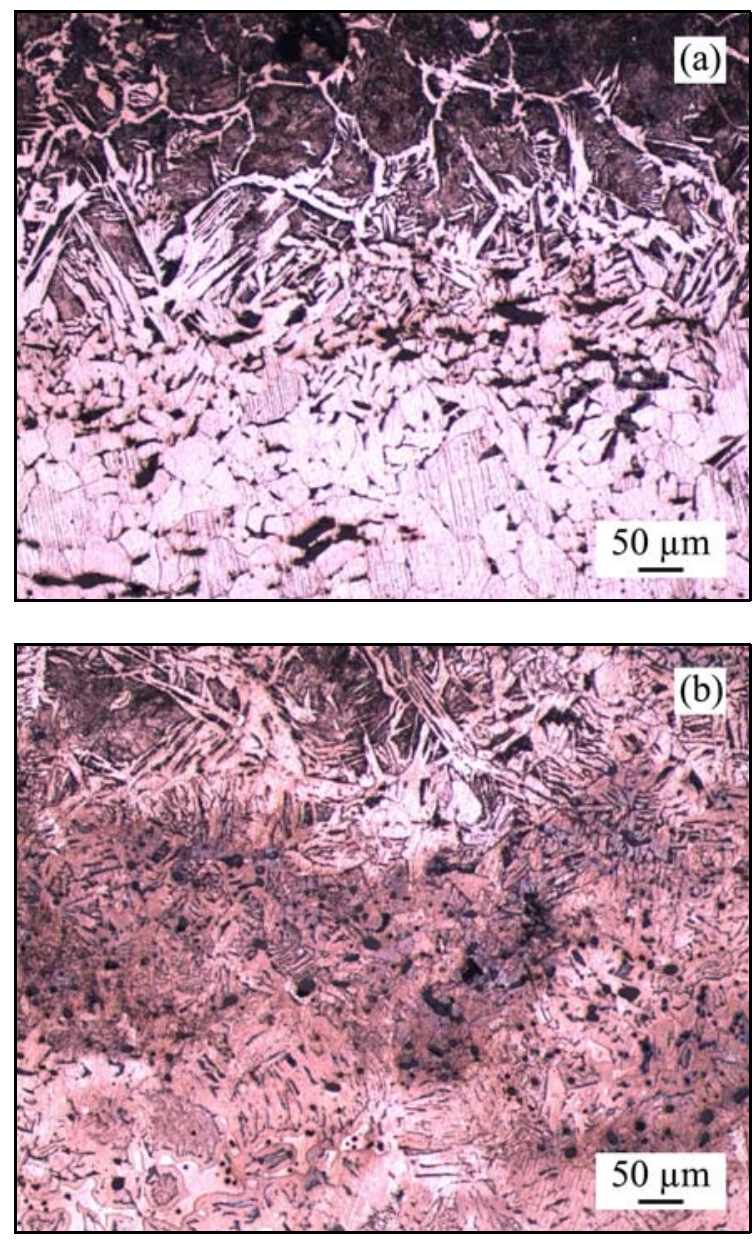

Fig. 7. Microstructures of surface carburization observed at $100 \times$ magnification for sample (a) 12 and (b) 21 .

the transition zone of high carbon to low carbon zone.

There are also widmanstaetten ferrite plates crossing the interiors of the larger prior austenite grains during smithing processes shown in Fig. 8 for sample 1. Microstructure consists of pearlite delineated by a network of cementite. Carbon could not diffuse out of the centres of the larger austenite grains to join the cementite forming at the grain boundaries during the subsequent cooling, so cementite ferrite plates grew inwards from the grain boundaries in order to consume the excess carbon in the grain interiors. Todorov and Khristov [19] discussed that the content of carbon, the cooling rate, and the size of austenite grains were the main factors determining the formation of widmanstaetten structures.

As seen from Fig. 9, during the smithing process, hammering yields different chemical composition zones. Pearlite and ferrite formation can be observed in region $\mathrm{A}$ and only ferrite formation in region $\mathrm{B}$. In Fig. 9a, it is clear that the same heat treatment is applied to both regions. Grains are homogenized by 

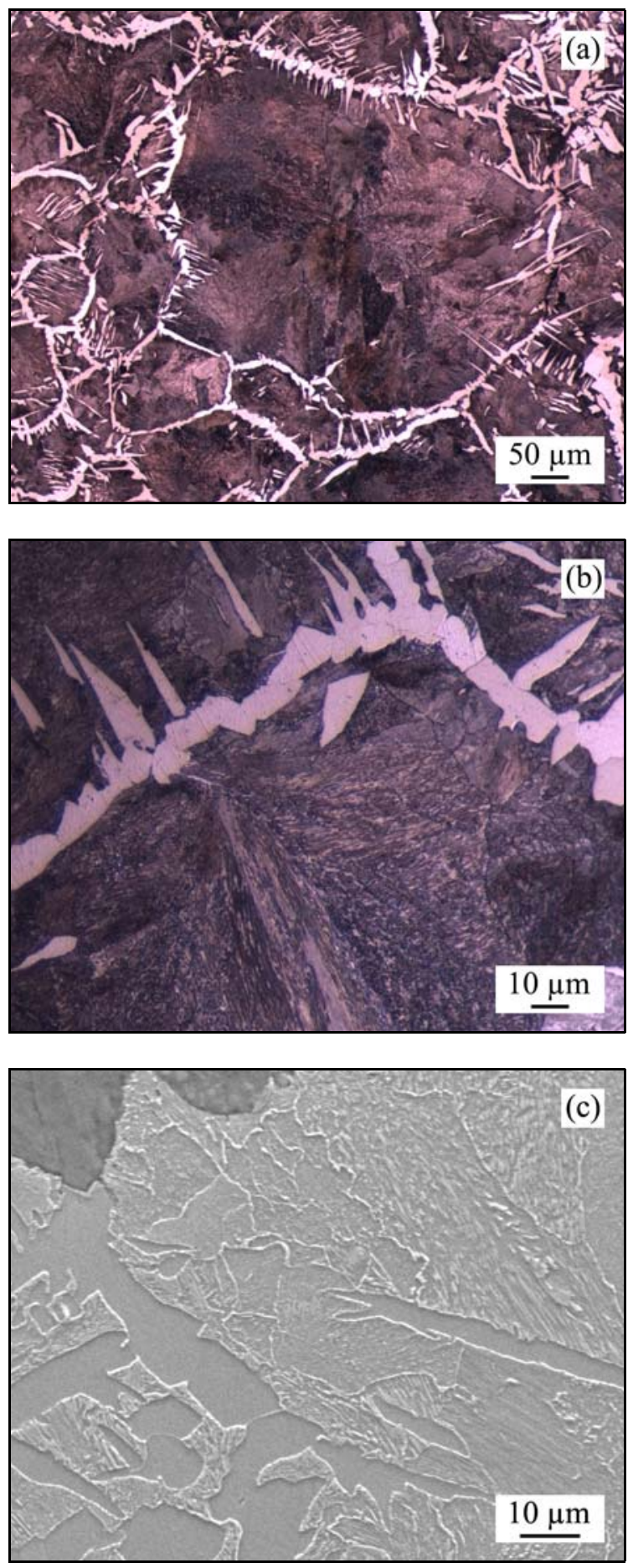

Fig. 8. Widmanstaetten structures in the carburization zones of sample 1 at (a) $100 \times$ by OM, (b) $500 \times$ by OM and (c) $1000 \times$ by SEM.

annealing after hammering. In Fig. 9b, it is clear that region $\mathrm{B}$ has another chemical composition where the austenite is stabilized as observed in grain boundary precipitations. The precipitation mechanism of $\mathrm{P}$ rich zones in iron grain boundaries is discussed by Piccardo et al. [20].
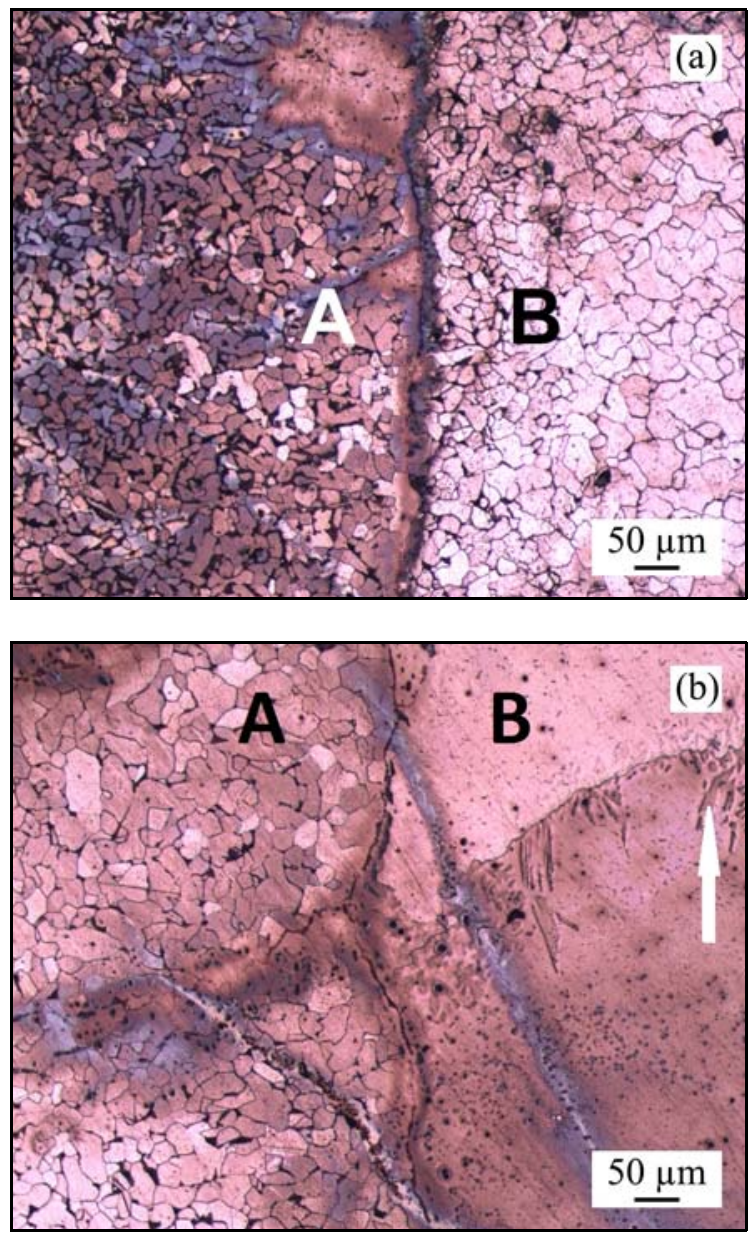

Fig. 9. The microstructures of transition for different zones in iron matrix.

Sample 27 is a good example to observe the effect of hammering (forging) during smithing process for homogeneously distributed ferrite and pearlite structures (Fig. 10). Randomly elongated and re-orientated ferrite and pearlite grains indicate forged structures. The nail is not annealed after forging process. In one of the 32 samples homogeneous spheroidization of carbon is observed in the microstructure of surface carburized nail. Ma et al. [21] studied equal channel angular pressing of medium carbon steel with $\sim 0.4 \mathrm{wt} . \% \mathrm{C}$. They found that the pearlite colonies were severely deformed and fragmented into irregular smaller shapes. Also, most of the ferrite and pearlite grains become elongated ones. Pass, both curvy and spheroidal cementite can be seen whereas after 4 passes, almost all cementite plates were broken into short ones or spheroids. Spheroidization of carbon in the pearlite sites is shown in Fig. 11.

\section{Conclusions}

Heterogeneous microstructural differences have 

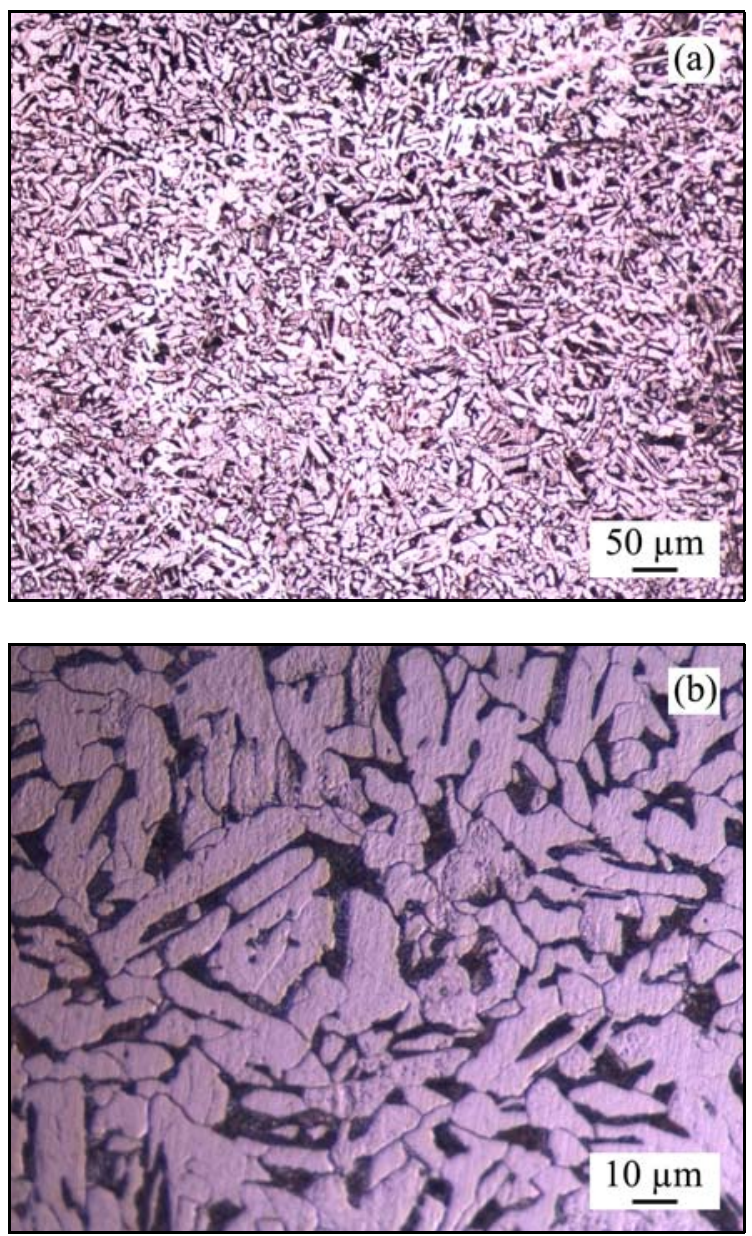

Fig. 10. Microstructure of elongated ferrite and pearlite grains after smithing at (a) $100 \times$ and (b) $500 \times$ magnification.

been found in iron nails according to chemical compositions after bloomery and smithing processes. The amount of carbon (C) is below $0.62 \mathrm{wt} . \%$ for such 8 nail samples which is in hypoeutectoid zone of Fe-C diagram. Ferrite is dominant in the microstructure of the centre zones of the nails. Also cementite and pearlite formations are observed. Surface carburization layers composed of pearlite and cementite in widmanstaetten structure are possible during smithing processes. Increasing amount of As, $\mathrm{P}$ and $\mathrm{Ni}$ decreases the diffusion rate of $\mathrm{C}$ on the surface and matrix. Hammering is not enough to remove all inclusions from the iron matrix. Slag inclusions are distributed unevenly with no apparent regularity. Nital can be used to determine the P, As and Ni rich zones in ferrite. Similar metal ores and bloomery technique are employed to investigate iron nails according to trace elements such as $\mathrm{P}, \mathrm{As}, \mathrm{Ni}, \mathrm{Cu}, \mathrm{Mn}$ amounts in the iron alloy. Further studies will focus on matching trace element amounts with possible iron ore sources in the near geography for provenance analysis. Compositions of oxide layers
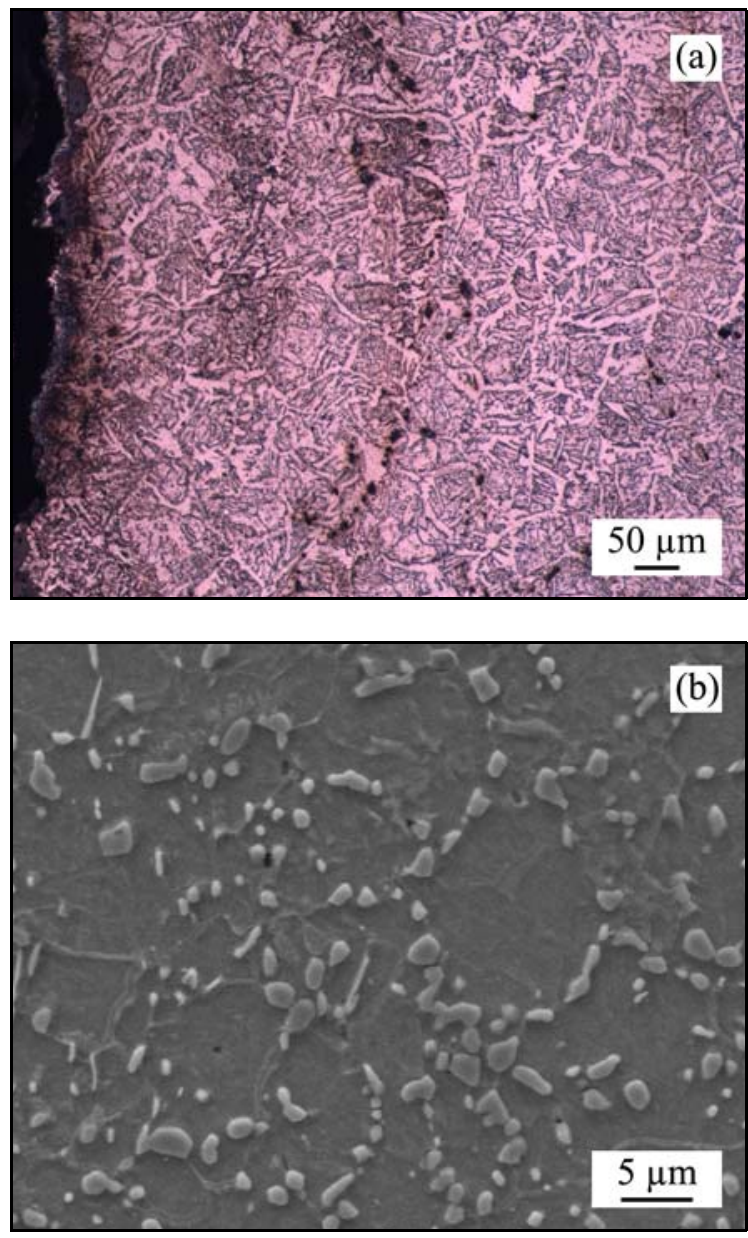

Fig. 11. Microstructure of spheroidized graphite in pearlite sites (a) from surface at $100 \times$ by $\mathrm{OM}$ and (b) at $2000 \times$ by SEM.

and inclusions will be analyzed by SEM and EDS for further archaeological and conservation interest.

\section{Acknowledgements}

The author is grateful to Prof. Dr. Ergün Lafli who supported the research of the ancient nails excavated during the archaeological project of Paphlagonia in 2006. The author also thanks the company Kocaer Rolling Mill, Izmir, and R\&D director Dursun Demirci who conducted elemental investigations by optical emission spectrometer.

\section{References}

[1] Lafli, E., Zäh, A.: Byzantinische Zeitschrift, 101, 2008, p. 681. (in German)

[2] Paynter, S.: Pre-Industrial Iron Works. English Heritage, May 2011.

[3] Ackerman, K. J., Killick, D. J.: Journal of Archaeological Science, 26, 1999, p. 1135. 
[4] Eliyahu-Behar, A., Shilstein, S., Raban-Gerstel, N., Goren, Y., Gilboa, A., Sharon, I., Weiner, S.: Journal of Archaeological Science, 35, 2008, p. 2895. doi:0.1016/j.jas.2008.06.004

[5] Wayman, M. L.: Materials Characterization, 45, 2000, p. 259.

[6] Cvikel, D., Ashkenazi, D., Stern, A., Kahanov, Y.: Materials Characterization, 83, 2013, p. 198. doi:10.1016/j.matchar.2013.06.012

[7] Charlton, M. F., Blakelock, E., Martinón-Torres, M. T., Young, T.: Journal of Archaeological Science, 39, 2012, p. 2280. doi:10.1016/j.jas.2012.02.037

[8] Abdu, B., Gordon, R.: Journal of Archaeological Science, 31, 2004, p. 979. doi:10.1016/j.jas.2003.12.011

[9] Eliyahu-Behar, A., Yahalom-Mack, N., Gadot, Y., Finkelstein, I.: Journal of Archaeological Science, 40, 2013, p. 4319. doi:10.1016/j.jas.2013.06.009

[10] Frame, L.: Journal of Archaeological Science, 37, 2010, p. 1700. doi:10.1016/j.jas.2010.01.030

[11] Blakelock, E., Martinón-Torres, M., Veldhuijzen, H. A., Young, T.: Journal of Archaeological Science, 36, 2009, p. 1745. doi:10.1016/j.jas.2009.03.032

[12] Miller, D.: Journal of Archaeological Science, 29, 2002, p. 1083. doi:10.1006/jasc. 2001.0758
[13] Iles, L.: Journal of Archaeological Science, 49, 2014, p. 423. doi:10.1016/j.jas.2014.05.029

[14] Aronsona, A., Ashkenazia, D., Barkaib, O., Kahanov, Y.: Materials Characterization, 78, 2013, p. 108. doi:10.1016/j.matchar.2013.01.004

[15] Navasaitis, J., Selskiene, A., Zaldarys, G.: Materials Science (MEDŽIAGOTYRA), 16, 2010, p. 113.

[16] Strobl, S., Haubner, R., Klemm, S.: Acta Metallurgica Slovaca Conference, 1, 2010, p. 661.

[17] Buchwald, V. F., Wivel, H.: Materials Characterization, 40, 1998, p. 73. doi:10.1016/S1044-5803(97)00105-8

[18] Ramesh Kumar, A.V., Balasubramaniam, R.: Corrosion Science, 40, 1998, p. 1169. doi:10.1016/S0010-938X(98)00024-9

[19] Todorov, R. P., Khristov, Kh. G.: Metal Science and Heat Treatment, 46, 2004, p. 49. doi:10.1023/B:MSAT.0000029601.58461.bd

[20] Piccardo, P., Ienco, M. G., Balasubramaniam, R., Dillmann, P.: Current Science, 87, 2004, p. 650.

[21] Ma, L. W., Wu, X., Xia, K.: Materials Forum, 32, 2008, p. 1. 